ISSN : $2302-1590$

E-ISSN: $2460-190 \mathrm{X}$

ECONOMICA

Journal of Economic and Economic Education Vol.4 No.2 (296-307)

\title{
PENGARUH KEPEMIMPINAN, MOTIVASI KERJA DAN KOMITMEN KERJA TERHADAP KINERJA GURU MADRASAH ALIYAH NEGERI (MAN) LUBUK ALUNG
}

\author{
Rika Verawati \\ Dosen program Studi Pendidikan Ekonomi STKIP PGRI Sumatera Barat \\ Jl. Gunung Panggilun No.1 Padang, Sumatera Barat \\ Email: zahiraunp@yahoo.co.id \\ submited:2016.06.23 reviewed: 2016.07.01 accepted: 2016.07.01 \\ http://dx.doi.org/10.22202/economica.2016.v4.i2.650
}

\begin{abstract}
This study aims to determine: 1) Leadership significant influence on the motivation of teachers Madrasah Aliyah Negeri (MAN) Lubuk Alung. Based on the analysis, the value thit $=0.166<$ ttab $=0.248$, with attention to both the magnitude of this means there is no significant effect between the leadership to motivate teachers in Madrasah Aliyah Negeri (MAN) Lubuk Alung or in other words the hypothesis is rejected. The second hypothesis proposed is "Leadership and Motivation significant influence on the commitment of teachers Madrasah Aliyah Negeri (MAN) Lubuk Alung". Based on the results of ANOVA has been done, the value Fhit $=10$ 657> Ftab = 3.19, taking into account both the magnitude of this means a significant difference between leadership and motivation on the commitment of teachers Madrasah Aliyah Negeri (MAN) Lubuk Alung. The third hypothesis proposed is Leadership, Motivation and commitment have significantly influenced teacher performance Madrasah Aliyah Negeri (MAN) Lubuk Alung.
\end{abstract}

\begin{abstract}
Abstrak
Penelitian ini bertujuan untuk mengetahui: 1) Kepemimpinan mempunyai pengaruh signifikan terhadap Motivasi guru Madrasah Aliyah Negeri (MAN) Lubuk Alung. Berdasarkan hasil analisis, diperoleh nilai $t_{\text {hit }}=0,166<t_{\text {tab }}=0,248$, dengan memperhatikan kedua besaran tersebut hal ini berarti tidak terdapat pengaruh signifikan antara kepemimpinan terhadap motivasi guru pada Madrasah Aliyah Negeri (MAN) Lubuk Alung atau dengan kata lain hipotesis yang diajukan ditolak. Hipotesis kedua yang diajukan adalah "Kepemimpinan dan Motivasi mempunyai pengaruh signifikan terhadap Komitmen guru Madrasah Aliyah Negeri (MAN) Lubuk Alung”. Berdasarkan hasil Anova yang telah dilakukan, diperoleh nilai $F_{\text {hit }}=10.657>F_{\text {tab }}=3$, 19, dengan memperhatikan kedua besaran tersebut hal ini berarti terdapat pengaruh yang signifikan antara kepemimpinan dan motivasi terhadap Komitmen pada guru Madrasah Aliyah Negeri (MAN) Lubuk Alung. Hipotesis ketiga yang diajukan adalah Kepemimpinan, Motivasi dan Komitmen mempunyai pengaruh signifikan terhadap Kinerja guru Madrasah Aliyah Negeri (MAN) Lubuk Alung
\end{abstract}

Keywords: Leadership, Work Motivation, Work Commitments And Teacher Performance

C2016 Prodi Pendidikan Ekonomi STKIP PGRI, Padang 


\section{PENDAHULUAN}

Dalam Undang-undang No. 20 Tahun 2003 tentang Sistem Pendidikan Nasional dijelaskan bahwa pendidikan adalah usaha sadar dan terencana untuk mewujudkan suasana belajar dan proses pembelajaran agar peserta didik secara aktif mengembangkan potensi dirinya untuk memiliki kekuatan spiritual keagamaan, pengendalian diri, kepribadian, kecerdasan, akhlah mulia, serta keterampilan yang diperlukan dirinya, masyarakat, bangsa dan negara.

Amanat yang disampaikan Undang-undang di atas setelah 60 tahun lebih Indonesia merdeka belum juga tercapai. Krisis ekonomi yang kemudian berlarut menjadi krisis multidimensional di Indonesia pasca rezim Orde Baru drastis mengakibatkan mutu pendidikan semakin merosot. Posisi Indonesia dalam peringkat Human Development Indeks (HDI), yaitu indeks perkembangan manusia berdasarkan komposisi peringkat pencapaian pendidikan, kesehatan dan penghasilan per kepala semakin menurun. Diantara 174 negara di dunia, Indonesia menempati urutan ke 102 pada tahun 2006, ke 99 pada tahun 1997, ke 107 pada tahun 1998, dan 109 pada tahun 1999. Di kawasan Brunei berada pada peringkat ke 36, Thailand berada pada peringkat ke 52, Malaysia berada pada peringkat ke 53 . Rendahnya indeks pengembangan manusia di Indonesia tersebut mengindikasikan bahwa rendahnya daya saing bangsa. Data yang dilaporkan The world Economic Forum, dalam Syahnur (2001) juga menunjukkan hal yang sama Indonesia memiliki daya saing yang rendah, yaitu menduduki urutan ke
37 dari 57 negara yang disurvei dunia.

Salah satu masalah dalam penyelengaraan pendidikan disekolah adalah tidak terlepas dari persoalan manajemen, kepemimpin dan komitmen guru dalam menyelengarkan pendidikan. Kepemimpinan yang diperani oleh seorang kepada sekolah diharapkan mampu meningkatkan mutu pendidikan dan dapat memberikan bimbingan dan arahan kepada tenaga pengajar yaitu guru. Kepemimpinan seorang kepala sekolah merupakan kekuatan penting dalam rangka pengelolaan sekolah, kunci utama kemampuan memimpin seorang kepala sekolah adalah secara efektif terletak pada sejauhmana ia dapat bertinfak menjadi seorang manajer yang efektif.

Akan tetapi pada Madrasah Aliyah Negeri (MAN) Lubuk Alung peneliti melihat fenomena yang ada, pimpinan Madrasah Aliyah Negeri (MAN) Lubuk Alung kurang memberikan arahan kepada para guru dalam bekerja. Sehingga para guru dalam melaksanakan tugas mengajar hanya pada bidang mengajar yang diwenangkan kepada mereka. Pimpinan madrasah juga tidak mengarahkan guru mengenai peningkatan kualitas pendidikan terhadap guru sehingga guru dalam mengajar hanya sebatas pada kewajiban mengajar saja. Dalam proses mengajar, guru akan bekerja dan melakukan aktifitas mengajaranya dengan serius hanya pada saat pemimpin madrasah melakukan tinjauan langsung ke ruang belajar atau kemajelis guru.

Seiring dengan kepemimpinan seorang kepala sekolah, guru juga merupakan faktor penting dalam proses pembelajaran. 
Tanpa guru maka pembelajaran dan tujuan dari sekolah tidak akan tercapai. Dengan demikian guru harus memiliki kemampuan yang handal untuk dapat melaksanakan tugas dan fungsinya sebagai seorang tenaga pendidik. Mengingat betapa pentingnya peranan guru dalam upaya peningkatan mutu pendidikan, guru dituntut memiliki komitmen yang baik terhadap tugas dan tanggung jawabnya.

Akan tetapi pada saat sekarang ini penulis melihat bahwa kinerja guru pada sekolah Madrasah Aliyah Negeri (MAN) Lubuk Alung sangat rendah. Hal ini dapat penulis ketahui dari observasi awal penulis ke sekolah. Penulis melihat bahwa dalam melaksanakan proses pembelajaran sebagian dari guruguru tersebut tidak membuat RPP (Rencana Proses Pembelajaran) yang merupakan langkah awal dari proses pengajaran bagi seorang guru dan buku paket yang digunakan guru dalam mengajar sangat minim, sebagian guru hanya mengandalkan buku kurikulum 1994, padahal kurikulum dan kompetensi mengajar guru menuntut kreatifitas dan kematangan guru dalam mengajarkan materi.

Penulis juga melihat kurangnya disiplin mengajar guru masuk ke kelas yang melebih dari waktu yang telah ditentukan. Lonceng berbunyi menandakan pelajaran dimulai, akan tetapi guru yang akan mengajar masih bercerita dan bercanda dengan rekan sesama guru di ruangan guru, hal ini yang belum disadari oleh guru-guru Madrasah Aliyah Negeri (MAN) Lubuk Alung.

Berdasarkan pengamatan penulis tersebut menunjukan bahwa kepemimpinan kepala sekolah pada
Madrasah Aliyah Negeri (MAN) Lubuk Alung belum optimal serta motivasi dan komitmen guru dalam melaksanakan disiplin dan peraturan lainnya masih dianggap rendah.

Berdasarkan latar belakang tersebut penulis tertarik untuk meneliti: "Pengaruh

Kepemimpinan, Motivasi kerja terhadap Kinerja Guru Madrasah Aliyah Negeri (MAN) Lubuk Alung"

\section{Kinerja Kerja Guru}

Dunia pendidikan tidak akan berhasil dan berkembang tanpa adanya kinerja yang baik dari semua pihak, dalam hal ini adalah guru. Guru yang memiliki kinerja yang baik maka akan menghasilkan prestasi kerja yang baik pula sehingga tercapainya tujuan dari pembelajaran. Menurut Ruky (2002:7) kinerja adalah: Elemen, unsur atau input yang harus didaya gunakan oleh organisasi untuk meningkatkan kinerja adalah manusia, teknologi (peralatan metode kerja) kualitas lingkungan fisik tentunya semakin baik pula dunia pendidikan. Akan tetapi optimalisasi kinerja ini tidak mudah untuk mencapainya, karena begitu banyaknya faktor yang akan mempengaruhi.

Menurut Malayu (2003:93) menyatakan bahwa kinerja adalah suatu hasil kerja yang dicapai seseorang dalam melaksanakan tugas-tugas yang dibebankan kepadanya atas kecakapan, pengalaman dan kesungguhan serta waktu.

Menurut Rivai (2005:14) kinerja adalah hasil atau tingkatan keberhasilan seseorang secara keseluruhan selama periode tertentu di dalam melaksanakan tugas 
dibandingkan dengan berbagai kemungkinan sepeti standar hasil kerja, target atau sasaran atau kriteria yang telah ditentukan terlebih dahulu dan telah disepakati bersama. Kinerja merupakan hasil pekerjaan yang mempunyai hubungan kuat dengan tujuan strategis organisasi, kepuasan konsumen dan memberikan kontribusi pada ekonomi (Amstrong, 1998:15). Sedangkan menurut Tiffin dan Cormick dalam Mangkunegara (2002:54) bahwa kinerja sebagai hasil kerja secara kualitas dan kuantitas yang dicapai oleh seorang pegawai dalam kemampuan melaksanakan tugasnya sesuai dengan tanggung jawab yang diberikan kepadanya.

\section{Kepemimpinan}

Kepemimpinan merupakan salah satu bentuk usaha suksesnya atau berhasilnya tujuan dari organisasi. Pengertian kepemimpinan telah banyak dikemukakan oleh para ahli. Menurut Mulyasa (2005:21) menyatakan kepemimpinan adalah suatu seni atau kemampuan seseorang dalam mempengaruhi tingkah laku bawahan. Selanjutnya Dinas Pendidikan Nasional (2000:11) mengemukakan kepemimpinan kepala sekolah sebagai cara atau usaha kepala sekolah dalam mempengaruhi, mendorong, membimbimg, mengarahkan, dan menggerakkan guru, siswa, orang tua siswa dan pihak lain yang terkait untuk bekerja, berperan guna mencapai tujuan yang telah ditetapkan. Senada dengan itu Departemen Pendidikan dan Kebudayaan (1998:9) mengemukakan bahwa kepemimpinan kepala sekolah adalah cara atau usaha kepala sekolah dalam mempengaruhi dan menggerakkan guru, staf, siswa, orangtua siswa, dan pihak lain yang terkait untuk berperan serta guna mencapai tujuan yang telah ditetapkan.

Adapun menurut Rivai (2007:2), definisi kepemimpinan secara luas meliputi: Proses mempengaruhi dalam menentukan tujuan organisasi, memotivasi perilaku pengikut untuk mencapai tujuan, mempengaruhi untuk memperbaiki kelompok dan budayanya. Selain itu juga mempengaruhi interpretasi mengenai peristiwa-peristiwa para pengikutnya, pengorganisasian dan aktivitas-aktivitas untuk mencapai sasaran, memelihara hubungan kerja sama dan kerja kelompok, perolehan dukungan dan kerja sama dari orangorang di luar kelompok atau organisasi.

Menurut Tasmara (2002:102) kepemimpinan berarti kemampuan mengambil posisi dan sekaligus memainkan peran (role) sehingga kehadiran dirinya memberikan pengaruh pada lingkungannya. Menurut Farland dalam Danim (2004:55) mengemukakan bahwa kepemimpinan adalah suatu proses di mana pimpinan dilukiskan akan memberi perintah atau pengaruh, bimbingan atau proses mempengaruhi pekerjaan orang lain dalam memilih dan mencapai tujuan yang telah ditetapkan.

\section{Motivasi Guru}

Organisasi

merupakan sekumpulan orang yang bekerja sama untuk mencapai tujuan bersama yang memiliki kebutuhan dan keinginan yang berbeda-beda satu dengan yang lainnya, hal ini berbeda karena fitrahnya manusia memiliki keunikan secara biologis maupun secara psikologis, dan berkembang atas dasar proses belajar yang 
berbeda pula (Suorihanto dkk, 2003:41).

Menurut Hamzah (2008:3) Istilah motivasi berasal dari kata motif yang dapat diartikan sebagai kekuatan dalam diri individu, yang menyebabkan individu tersebut bertindak atau berbuat. Motif tidak dapat diamati secara langsung, tetapi dapat diinterpretasikan dalam tingkah lakunya, berupa rangsangan, dorongan, atau pembangkit tenaga munculnya suatu tingkah laku tertentu.

Menurut Hamzah (2008:63) motivasi berasal dari kata motif yang dapat diartikan sebagai tenaga pengerak yang mempengaruhi kesiapan untuk mulai melakukan rangkaian kegiatan dalam suatu perilaku. Pada dasarnya motivasi tidak dapat diamati secara langsung, tetapi dapat diinterpretasikan dari tingkah lakunya. Menurut Malone dalam Hamzah (2008:66) membedakan dua bentuk motivasi yang meliputi:

a. Motivasi instrinsik, yakni motivasi yang timbul tidak memerlukan rangsangan dari luar karena memang telah ada pada diri individu itu sendiri, yaitu sesuai atau sejalan dengan kebutuhan.

b. Motivasi ekstrinsik, yakni motivasi yang timbul karena adanya rangsangan dari luar individu.

\section{Komitmen Kerja}

Sahertian (1994:44) mengartikan komitmen kerja sebagai suatu kecenderugan dalam diri seseorang untuk merasa aktif dengan rasa penuh tanggung jawab. Dengan adanya komitmen yang tinggi dengan demikian seseorang yang terlibat aktif dengan penuh tanggung jawab dalam suatu pekerjaan yang ditekuni akan sanggup menetapkan keputusan dirinya sendiri dan melaksanakan pekerjaan tersebut dengan kesungguhan hati. Komitmen juga merupakan keputusan atau perjanjian seseorang dengan dirinya sendiri untuk melaksanakan atau tidak melakukan sesuatu pekerjaan. Seseorang yang telah memiliki suatu komitmen maka ia tidak ragu-ragu dalam menentukan sikap bertanggung jawab terhadap keputusan yang diambil.

Sahertian (1994:87) menjelaskan bahwa komitmen dan kepedulian dapat timbul bila ada kecintaan terhadap tugas dan tanggung jawab. Semua orang secara alami memiliki komitmen. Akan tetapi komitmen semua orang tidak akan pernah sama. Ada orang yang memiliki komitmen kerja rendah dan ada pula yang memiliki komitmen kerja tinggi. Hal ini akan ditentukan oleh tingkat perkembangan dan proses kejiwaan yang berbeda sacara ilmiah.

Menurut Nawawi dan Martini (1993:160) menjelaskan keteguhan hati untuk melakukan suatu pekrjaan dianggap dan diyakini sebagai suatu komitmen. Komitmen juga diartikan sebagai suatu ketetapan hati di dalam diri seseorang untuk menrima atau menolak satu atau lebih tujuan, dan menentukan perbuatan atau kegiatan. Seseorang yang telah menetapkan komitmen untuk dirinya dengan tekat akan sanggup untuk bekerja keras. Prinsip dan tekadnya untuk selalu berbuat selalu diwujudkannya sebagai tanggung jawab yang sesuai dengan apa yang diucapkan, dan bahkan bukan hanya untuk kepentingan dirinya.

Israel (1990:78) mengatakan komitmen seseorang dapat naik dan dapat pula turun terhadap tugasnya 
yang sangat dipengaruhi oleh sikap. Sikap positif yang ada pada pekerjaan membuat seseoarang betah bekrja dan mampu bertahan sebagai anggota organisasi. Rasa kepedulian seseorang terhadap tugas dan kepentingan umum organisasi, dan bukan saja karena atas kepentingan pribadi, akan memberikan kontribusi yang sangat berarti bagi organisasi.

\section{METODE PENELITIAN}

Dalam penelitian ini penulis menggunakan desain penelitian metode deskriptif dan asosiatif. Penelitian deskriptif adalah penelitian yang dimaksudkan untuk menyelidiki keadaan, kondisi, atau hal-hal lain terhadap suatu objek atau wilayah yang diteliti. Sedangkan penelitian asosiatif suatu penelitian yang mencari hubungan antara satu variabel dengan variabel lain, yaitu simetris kausal dan interaktif. Dengan disain penelitian deskriptif dan asosiatif, maka penelitian memungkinkan untuk menggambarkan hubungan antar variabel, menguji hipotesis, mengembangkan generalisasi, dan mengembangkan teori yang memiliki validitas yang universal (Arikunto, 2010:3). Penelitian ini akan dilakukan pada guru MAN Lubuk Alung.

\section{Jenis Data Dan Sumber Data}

\section{Data primer}

Data primer yaitu data yang didapat dari sumber pertama baik dari individup maupun perorangan seperti hasil dari wawancara dan dan hasil pengisian kuesioner yang biasa dilakukan oleh peneliti (Umar, 2005:41). Data primer adalah data yang didapat dari jawaban guru MAN Lubuk Alung selaku responden terhadap rangkaian peryataan yang akan digunakan oleh peneliti terkait dengan serangkaian peryataan yang akan digunakan yakni kepemimpinan (X1), (X2) motivasi kerja, Komitmen kerja (X3) dan kinerja guru $(\mathrm{Y})$, yang diperoleh melalui penggunaan kuesioner yang akan disebarkan pada guru MAN Lubuk Alung.

2. Data sekunder

Data sekunder yaitu data yang diperoleh secara tidak langsung dari objeknya yakni berupa data yang diambil dari kantor MAN Lubuk Alung.

\section{PEMBAHASAN}

\section{a. Pengaruh Kepemimpinan terhadap Motivasi.}

Hasil analisis penelitian menunjukkan bahwa pengaruh yang kepemimpinan terhadap motivasi pada guru Madrasah Aliyah Negeri (MAN) Lubuk Alung kurang signifikan, padahal seharusnya berdasarkan kajian teori yang telah dipaparkan sebelumnya bahwa kepemimpinan berpengaruh terhadap motivasi guru sebagaimana dikemukakan (Rivai:2006, Taufiq Bahauddin:2001, dan Siagian:2003). Hal ini menunjukkan bahwa kepemimpinan yang diterapkan pada Madrasah Aliyah Negeri (MAN) Lubuk Alung belum optimal sehingga pengaruhnya terhadap Motivasi kurang begitu nampak.

Hal ini menunjukkan bahwa pengaruh kepemimpinan terhadap motivasi perlu ditingkatkan. Secara empirik hal ini ditunjukkan bahwa pemimpin tidak banyak berperan dalam menciptakan motivasi yang kondusif. Motivasi pada penelitian ini diarahkan pada suasana tata letak ruangan, ventilasi dan peralatan atau sarana untuk menunjang lancarnya pelakasanaan kerja guru. Motivasi seperti ini lebih banyak berkaitan 
dengan pendanaan, dimana peran pimpinan tidak begitu besar karena untuk merubah suasana motivasi tergantung dari dana yang ada di pusat.

Hasil penelitian yang menunjukkan bahwa kepemimpinan tidak berpengaruh terhadap motivasi guru Madrasah Aliyah Negeri (MAN) Lubuk Alung terkait dengan sifat dan tugas yang diemban oleh para guru. Tugas dan keputusan sangat tergantung pada peraturan dan ketentuan yang telah ditetapkan oleh pemerintah pusat seperti Undangundang, peraturan pemerintah, keputusan menteri, dan standarisasi dari pusat sehingga pimpinan Madrasah lebih banyak bersifat fasilitator dan koordinator dalam pelaksanaan tugas.

\section{b. Pengaruh Kepemimpinan dan Motivasi terhadap Komitmen.}

Pengaruh kepemimpinan dan motivasi terhadap komitmen menunjukkan bahwa kepemimpinan dan motivasi berpengaruh signifikan terhadap komitmen guru maupun terhadap aktifitas guru pada Madrasah Aliyah Negeri (MAN) Lubuk Alung. Penelitian ini sejalan dengan teori yang telah dikemukana bahwa karakter kepemimpinan yang kuat akan memiliki dampak positif terhadap organisasi terutama terhadap pemenuhan komitmen dari seluruh anggota organisasi, antara lain kepemimpinan yang baik akan dapat mengarahkan perilaku guru sesuai dengan tujuan Madrasah Aliyah Negeri (MAN) Lubuk Alung.

Hasil penelitian menunjukkan bahwa kepemimpinan pada Madrasah Aliyah Negeri (MAN) Lubuk Alung telah berjalan dengan baik. Hal ini dapat dilihat dari sikap pimpinan yang selalu memberikan motivasi, menumbuhkan rasa percaya diri kepada guru, memberikan kepercayaan dalam bekerja, menjaga hubungan baik, menempatkan para guru sesuai dengan profesi dan keahliannya dalam mengajar dan menggalang kebersamaan untuk mencapai tujuan Madrasah bukan individu.

Kondisi ini sesuai dengan pendapat Robbins (2003:36) dan Siagian (2002:97) menyatakan faktor - faktor penting yang mendorong komitmen adalah pekerjaan yang secara mentalitas memberikan tantangan, penghargaan yang layak, kondisi kerja yang menunjang dan rekan sekerja yang mendukung, begitu pula menurut Herzberg dalam McKeena (2000:186) menyimpulkan rasa puas guru dalam bekerja berasal dari pekerjaan yang menantang, tanggung jawab ekstra, prestasi personal, pengakuan dari atasan dan kemajuan karir seseorang, kepemimpinan adalah pendorong bagi penciptaan komitmen guru yaitu dengan memberikan arahan yang baik dan dapat diterima oleh guru, maka guru akan senang dalam bekerja, begitu pula dengan selalu memberikan reward berupa pujian dan sapaan yang ramah akan menciptakan komitmen bagi para guru, kepemimpinan dapat diandalkan apabila pemimpin dapat memberi kepercayaan dan nilai-nilai yang berkembang dalam suatu organisasi dan mengarahkan perilaku segenap anggota organisasi yang mengacu ke suatu sistem yang telah disepakati bersama dan akan diikuti oleh seluruh guru. Sehingga kepemimpinan sangat menentukan etika kerja, dan akan munculah perasaan puas dalam bekerja dari seluruh anggota organisasi. 


\section{c. Pengaruh Kepemimpinan, Motivasi dan Komitmen terhadap Kinerja Guru .}

Hasil penelitian ini juga menunjukkan bahwa terdapat pengaruh yang signifikan antara kepemimpinan, motivasi dan komitmen terhadap kinerja guru Madrasah Aliyah Negeri (MAN) Lubuk Alung. Signifikansi pengaruh variabel kepemimpinan, motivasi, dan komitmen secara bersama-sama terhadap kinerja guru ditentukan oleh saling mendukung dan saling berhubungannya variabel yang diteliti satu sama lainnya. Kepemimpinan secara langsung dapat meningkatkan kinerja guru, dan juga dapat dilakukan dengan melalui variabel intervening (perantara) komitmen, dengan meningkatnya komitmen maka akan meningkatkan kinerja.

Motivasi secara langsung dapat mempengaruhi kinerja guru, dan motivasi juga dapat mempengaruhi kinerja dengan melalui variabel intervening komitmen, hal ini berarti motivasi dapat mempengaruhi komitmen dan dengan komitmen guru dapat mempengaruhi kinerja guru. Hal ini berarti untuk meningkatkan kinerja guru dapat dilakukan dengan cara meningkatkan variabel kepemimpinan dan motivasi secara langsung ataupun melalui komitmen guru.

Hal ini berimplikasi bahwa apabila terjadi penurunan pada salah satu variabel tersebut maka kinerja guru juga akan menurun. Meningkatnya kepemimpinan akan menyebabkan baiknya komitmen guru, motivasi yang kondusif juga akan meningkatkan komitmen dan komitmen akan meningkatkan kinerja.
Temuan penelitian ini sejalan dengan pendapat Nitiseminto (1982:105) bahwa kinerja seseorang dipengaruhi oleh beberapa faktor seperti (1) Motivasi, tingkat komitmen pada tugas, (2) adanya pemberian imbalan yang adil, (3) motivasi kerja, (4) Komitmen , dan (5) prilaku pimpinan. Sedangkan Arikunto (1990:65) menyatakan bahwa ada dua faktor yang mempengaruhi kinerja seseorang yaitu faktor internal dan faktor eksternal. Yang termasuk faktor internal adalah: (1) sikap, (2) minat, (3) intelegensi, (4) motivasi, dan (5) kepribadian. Sedangkan yang termasuk faktor eksternal adalah: (1) kepemimpinan , (2) sarana dan prasarana, (3) insentif atau gaji, (4) Komitmen , (5) suasana kerja, dan (6) Motivasi.

Dari hasil pengaruh langsung dan tidak langsung variabel dapat dilihat bahwa nilai pengaruh langsung motivasi lebih besar terhadap kinerja guru dari pada kepemimpinan dan komitmen. Oleh karena itu untuk meningkatkan kinerja yang lebih baik maka dapat dilakukan dengan cara meningkatkan motivasi kearah yang lebih baik. Untuk meciptakan motivasi yang baik diperlukan keterlibatan peran aktif pimpinan dan seluruh pegawai secara bersama-sama untuk menciptakannya. Karena jika salah satu komponen saja yang tidak berperan serta maka motivasi yang kondusif tidak akan tercipta, dan jika motivasi tidak baik akan menurunkan kinerja guru dalam melaksanakan tugas.

Pengaruh kepemimpinan dan motivasi terhadap aktivitas guru lebih besar pengaruh langsungnya dibandingkan dengan pengaruh tidak langsung melalui variabel 
intervening (perantara) komitmen, maknanya adalah komitmen guru sudah tidak menjadi permasalahan mendasar karena komitmen tidak bisa hanya diukur dengan materi tetapi dengan adanya kepemimpinan yang dapat mengayomi bawahan dan motivasi yang kondusif membuat guru bersemangat dalam bekerja yang pada akhirnya akan meningkatkan kinerja mereka.

Hasil analisis di atas juga menunjukkan bahwa kepemimpinan berpengaruh secara langsung terhadap komitmen guru dan juga berpengaruh langsung kepada kinerja guru. Begitu juga dengan motivasi yang baik akan berpengaruh terhadap puas tidaknya guru dan berdampak pada kinerja guru. Guru yang merasa puas dengan pekerjaan yang dilakukan akan meningkatkan kinerja mereka, sebaliknya guru yang tidak puas dengan pekerjaan yang mereka lakukan akan menurunkan kinerja.

Hasil analisis juga mengungkapkan bahwa pengaruh faktor lain terhadap komitmen yang tidak diteliti relatif besar. Hal ini menunjukkan masih ada faktorfaktor yang sangat berpengaruh terhadap komitmen yang tidak diteliti seperti insentif atau imbalan kerja, pengembangan diri untuk meningkatkan karir, dan sistem penempatan guru sesuai bidang dan keahliannya. Begitu juga dengan pengaruh faktor lain terhadap kinerja relatif besar tetapi masih lebih besar pengaruh faktor lain terhadap aktifitas kerja. Hal ini menunjukkan bahwa untuk mengukur kinerja guru secara kompehensif tidak bisa hanya dilakukan dengan mengukur kepemimpinan, motivasi dan komitmen tetapi harus dilihat dan diinventaris faktor-faktor apa saja yang berpengaruh diluar faktor yang telah diteliti ini. Koefisien analisis jalur yang terbentuk setelah penelitian dilakukan terhadap responden guru Madrasah Aliyah Negeri (MAN) Lubuk Alung beserta faktor lain yang mempengaruhinya dapat dilihat pada gambar berikut:

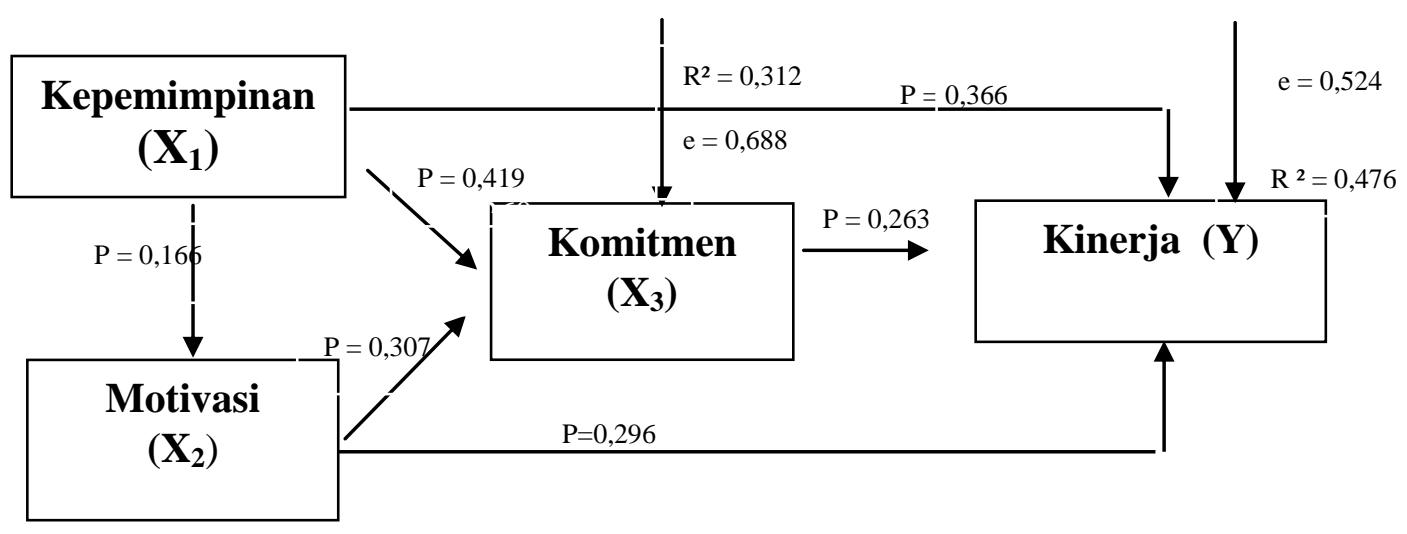

Gambar 1. Hasil Penelitian 
Berdasarkan hasil penelitian
pembahasan sebagaimana dipaparkan dalam tabel 4.11 dan gambar 4.2 di atas, maka dapat dilihat bahwa pengaruh langsung kepemimpinan terhadap aktifitas guru lebih besar apabila dibandingkan dengan pengaruh tidak langsung. Selain itu, pengaruh langsung motivasi terhadap kinerja guru juga lebih besar apabila dibandingkan dengan pengaruh tidak langsung. Demikian pula halnya dengan komitmen guru.

Berdasarkan paparan hasil penelitian dan bahasan tersebut di atas dapat dikemukakan bahwa kinerja dipengaruhi oleh faktor kepemimpinan, motivasi serta komitmen guru. Kepimpinan yang dijalankan dengan baik dan benar, motivasi yang kondusif dapat mendorong guru untuk mencapai kepuasan dalam bekerja yang pada akhirnya dengan kondisi tersebut aktifitas kerjanya akan semakin tinggi dan meningkat.

\section{Uji Hipotesis}

\section{a. Hipotesis Pertama}

Hipotesis pertama yang diajukan adalah "Kepemimpinan mempunyai pengaruh signifikan terhadap Motivasi guru Madrasah Aliyah Negeri (MAN) Lubuk Alung ". Berdasarkan hasil analisis, diperoleh nilai $\mathbf{t}_{\text {hit }}=\mathbf{0 , 1 6 6}<\mathbf{t}_{\mathbf{t a b}}=$ $\mathbf{0 , 2 4 8}$, dengan memperhatikan kedua besaran tersebut hal ini berarti tidak terdapat pengaruh signifikan antara kepemimpinan terhadap motivasi guru pada Madrasah Aliyah Negeri (MAN) Lubuk Alung atau dengan kata lain hipotesis yang diajukan ditolak.

\section{b. Hipotesis Kedua}

Hipotesis kedua yang diajukan adalah "Kepemimpinan dan Motivasi mempunyai pengaruh signifikan terhadap Komitmen guru Madrasah Aliyah Negeri (MAN) Lubuk Alung”. Berdasarkan hasil Anova yang telah dilakukan, diperoleh nilai $\mathbf{F}_{\text {hit }}=\mathbf{1 0 . 6 5 7}>\mathbf{F}_{\text {tab }}$ $=3,19$, dengan memperhatikan kedua besaran tersebut hal ini berarti terdapat pengaruh yang signifikan antara kepemimpinan dan motivasi terhadap Komitmen pada guru Madrasah Aliyah Negeri (MAN) Lubuk Alung atau dengan kata lain hipotesis yang diajukan dapat diterima.

\section{c. Hipotesis Ketiga}

Hipotesis ketiga yang diajukan adalah "Kepemimpinan, Motivasi dan Komitmen mempunyai pengaruh signifikan terhadap Kinerja guru Madrasah Aliyah Negeri (MAN) Lubuk Alung". Berdasarkan hasil Anova yang telah dilakukan, diperoleh nilai $F_{\text {hit }}=\mathbf{1 3 , 9 1 5}>F_{\text {tab }}=\mathbf{2 , 8 0 6}$, dengan memperhatikan kedua besaran tersebut hal ini berarti terdapat pengaruh yang signifikan kepemimpinan, motivasi dan komitmen terhadap kinerja guru Madrasah Aliyah Negeri (MAN) Lubuk Alung, dengan kata lain hipotesis yang diajukan dapat diterima.

\section{PENUTUP}

Penelitian ini meneliti tentang pengaruh antara kepemimpinan, motivasi, dan komitmen terhadap kinerja guru Madrasah Aliyah Negeri (MAN) Lubuk Alung dan setelah dilakukan penelitian didapat hasilnya, maka ditarik kesimpulan bahwa: 
1. Kepemimpinan dan motivasi berpengaruh positif dan signifikan terhadap komitmen, walaupun secara sendiri-sendiri pengaruh kepemimpinan belum signifikan. Hal ini menunjukan bahwa semakin baik kepemimpinan dan motivasi, dan komitmen akan semakin meningkat.

2. Kepemimpinan, motivasi, dan komitmen secara bersama-sama berpengaruh signifikan terhadap kinerja guru Madrasah Aliyah Negeri (MAN) Lubuk Alung. Hal ini menunjukkan bahwa tinggi rendahnya kinerja guru ditentukan oleh baik tidaknya kepemimpinan, motivasi dan komitmen guru.

3. Kinerja guru Madrasah Aliyah Negeri (MAN) Lubuk Alung berada pada kategori baik. Hasil penelitian ini menunjukkan bahwa tinggi rendahnya Kinerja guru baik secara langsung dan tidak langsung dipengaruhi oleh kepemimpina, motivasi dan komitmen yang saling terkait antara satu dengan lainnya.

\section{B. Saran}

Berdasarkan paparan kesimpulan di atas, dapat dikemukakan beberapa saran sebagai berikut:

1. Kepada kepala sekolah Madrasah aliyah Negeri (MAN) Lubuk Alung diharapkan dapat melakukan hal-hal sebagai berikut:

a. Berhubungan dengan kinerja guru; 1) dalam melaksanakan aktifitas mengajar para guru dapat mempersiapkan terlebih dahulu materi yang akan di ajarkan sesuai dengan kompetensi dasar dan dapat merumuskan tujuan instruksional khusus yang sesuai dengan indikator yang telah disusun secara lengkap, 2) dalam pelaksanaan proses pembelajaran para guru dapat mengelola kelas dengan baik dan memantau kemajuan belajar siswa, 3) dalam pelaksanaan evaluasi belajar siswa guru dapat memberikan penilaian terhadap kemajuan belajar siswa secara objektif dan didasarkan pada pengamatan sikap siswa, 4) dalam pelaksanaan evaluasi belajar siswa guru dapat menganalisis soal untuk mengetahui validitas dan reliabilitas soal.

b. Berhubungan dengan kepemimpinan diharapkan pimpinan; 1) memperlakukan para guru maupun staf sebagai mitra kerja dalam mencapai tujuan organisasi, 2) memberikan dorongan atau motivasi untuk dapat bekerja lebih baik, 3) memperbaiki langkah-langkah kerja menjadi lebih efektif dan efisien, serta memberi kepercayaan lebih luas kepada guru agar guru dapat menumbuhkan kreativitas dalam bekerja.

c. Berhubungan dengan motivasi diharapkan; 1) dalam berinteraksi guru harus dapat menjalin hubungan yang baik dan terbuka, 2) dalam melaksanakan aktifitas pembelajaran guru dapat memotivasi diri untuk lebih meningkatkan kreatifitas dan inovatif dalam melaksanakan tugas mengajarnya, 3) guru dapat menampakkan prestasi kerja yang baik dalam menjalankan tugas dan kewajibannya.

d. Berhubungan dengan komitmen diharapkan; 1) dalam menjalankan tugas, guru dapat menjalankan tugas-tugas mengajar dengan baik, 2) guru 
dapat bekerja sama untuk mewujudkan tujuan, visi dan misi sekolah, 3) guru dapat menjalankan tugas sesuai dengan perintah pimpinan sekolah.

2. Kepada para guru Madrasah Aliyah Negeri (MAN) Lubuk Alung; diharapkan untuk meningkatkan wawasan, pengetahuan dan keterampilannya dalam bekerja serta menjalin hubungan yang harmonis baik dengan pimpinan maupun dengan guru lain serta ikut menciptakan motivasi yang kondusif dalam upaya meningkatkan kinerja.

3. Kepada peneliti selanjutnya; diharapkan dapat memperluas kajian tentang kinerja guru pada aspek yang belum diteliti pada penelitian ini, sehingga mendapatkan gambaran yang lebih komprehenif tentang kinerja beserta faktor-faktor yang mempengaruhinya.

\section{DAFTAR PUSTAKA}

10.22202/economica.2016.v4.i2.650 Arikunto, Suharsimi. 2002 Organisasi dan Administrasi Pendidikan Teknologi dan Kejuruan, Jakarta: PT. Coca Cola Bottling Indonesia central Sumatera, raja Grafindo Indonesia.

Hamzah ， B Uno. 2008. Teori Motivasi \& Pengukurannya. Jakarta: PT. Bumi Aksara.

Hasibuan, Malayu, SP. 2001. Manajemen Sumber Daya Manusia. Jakarta : Bumi Akasara.
Panggabean, Mutiara, S. 2004. Komitmen Organisasi seagai Mediator Variabel Bagi Pengaruh Kepuasan Kerja terhadap Keinginan untuk Pindah Kerja. Jurnal Bisnis dan Akuntansi Vol 6 (1) (April);90-114

Rivai, Veithzal. 2005. Manajemen Sumber Daya Manusia Untuk Perusahaan. Jakarta: PT. Raja Grafindo Persada.

Robbins Stephen. 2001. Perilaku Organisasi, Versi bahasa Indonesia, edisi kedelapan, PT. Prenhalindo, Jakarta.

Panggabean, Mutiara, S. 2004. Komitmen Organisasi seagai Mediator Variabel Bagi Pengaruh Kepuasan Kerja terhadap Keinginan untuk Pindah Kerja. Jurnal Bisnis dan Akuntansi Vol 6 (1) (April);90-114

Sugiyono. 2003. Metodologi Penelitian Administrasi. Bandung: Tarsito.

2007.Metode
Penelitian

Bandung:CV. Alpha Beta.

Timpe, A. Dale. 1993. Kinerja, Jakarta: PT. Gramedia, Pustaka Umum.

Tohardi, Ahmad. 2002. Pemahaman Praktis Manajemen Sumber Daya Manusia. Bandung : Mandar Maju

Umar, Husein. 1999. Metode penelitian untuk Skripsi dan Tesis Bisnis. Jakarta: Grafindo

Undang-undang No. 20 Tahun 2003 tentang Sistem Pendidikan Nasional. 